\title{
The Effect of Diabetes Audio Visual Learning Method for Improving Medical Skills of Surgical Nursing
}

\author{
Robiul Fitri Masithoh ${ }^{1 *}$, Estrin Handayani ${ }^{1}$ \\ ${ }^{1}$ Department of Nursing, Universitas Muhammadiyah Magelang, Magelang, Indonesia \\ *Corresponding author.Email: robiulfitri83@ummgl.ac.id
}

\begin{abstract}
An interactive video tutorial guiding students to understand a material through visualization. Students can interactively participate in practicum activities at laboratory has been teach in the videos. This research is a quasi-experimental study using 50 respondents taken by purposive sampling D3 nursing students. The data is obtained by using the chi square statistical test and Mann Whitney or non-parametric test. The results of this study have the effect of learning using audio-visuals and demonstrations in the control group and the intervention group with $\mathrm{p}$ value $0.000(\mathrm{p}<0.05)$. The average difference in the intervention group was 26 and the control group was 20 . Therefore, the use of instructional media with audio visual has a better influence on the ability of students to do diabetic foot exercises compared to using demonstration learning media.

Keywords: diabetes, audio visual learning, medical skills, surgical nursing
\end{abstract}

\section{INTRODUCTION}

The development of information technology is one of the exponents for developing learning innovations especially in learning media. The method currently being developed is to optimize the computer as a learning medium [1]. One of that included in the learning media used to make learning efficiency in an abstract learning model is optimizing audio visual facilities such as video. Video can assist student in sight and hearing. It is expected to ease understanding of concepts, absorbing learning more clearly and interestingly. Besides, it is presumed that the material will be more directed and optimal during the learning [2]. Video, a communication medium that combines elements of sound/sound and images with all the preparation techniques that are based on the degree of its use (use ware), is largely determined by the preparation of the cultivation of software namely material/messages and hardware in the form of production equipment. Teachers can make adjustments and increase creativity in the process of delivering teaching contents so that they become more memorable and easier in line with the expectation and characteristics of students. An interactive video tutorial guides student to understand a material through visualization. Students can interactively participate in practicum activities in accordance with what is taught in the video.

One of material that can be taught by video is Diabetes foot Gymnastic. Diabetes foot gymnastics is a learning clinical nursing skill or it more specifically is entered in the surgical medical nursing stage and is a part of community nursing. To understand diabetes foot gymnastics concepts visually and auditory there are several kinds of methods used. One of them is by using video. Learning through video based on material is more advance than traditional learning (face to face class). However, there is no empirical study of the development of instructional videos in improving the ability of diabetes foot exercises to meet the core competencies of nursing skills and in this section an in-depth study is needed [3]. The purpose of this research is to compile and develop effective learning videos for enhancing diabetes foot gymnastic skills for students, to describe the effectiveness of learning videos in increasing students' knowledge and skills in doing diabetes foot exercises, and to know the effect of the use of learning videos on student skills in doing diabetic foot exercises.

\section{METHOD}

This research is a quantitative study using the quasi experimental design method and research design using pretest and post-test control groups. Respondents would be divided into two groups which are the treatment group and the control group. The treatment group is the intervention group and the control group are the comparison group. All groups would be assessed early (pre-test) and after treatment would be assessed (post-test). The population in this study was all semester 3 Diploma III of nursing students who were taking Medical Surgical nursing courses. The research sample chosen were 50 students consisting of 25 students experimental group and 25 -students control group. The experimental results are in the form of written test scores and practice test results which are then analysed. Scores obtained in experiments using the normality test determine the test used. Data normality test used the Kolmogorov-Smirnov test. And the value or data distributed was not normal, then the data analysis used Mann Whitney and Wilcoxon. Before the data analysis performed, the Mann Whitney test was performed because the data was not normally distributed. Homogeneity test was performed to find out whether the data is homogeneous or not. Data collection procedures of this study which taking a score of both the written test and practice test carried out several stages, namely:

Pre-Test Stage. It is the stage in which the object of research/student is immediately told to work on test 
questions both written tests and practical tests. At this stage, students have not been introduced to diabetes foot exercises and video foot exercises for diabetes. All students are included at this stage both students who belong to the experimental group and students who belong to the control group.

Research Implementation Stage. It is the stage in which the students have been introduced to interactive tutorials and videos on diabetes foot exercises and began to observe the activity of students in using the two sets of research to work on exercises. Students included at this stage are only students who belong to the experimental group

Post Test Stage. It is the stage in which the object of research/student is immediately asked to do test questions both written test which is the same as the questions in the pre-test and practice tests. At this stage students are forbidden to cooperate or ask their friends. All students are included at this stage both students who belong to the experimental group and students who belong to the control group. Time to do the questions in both the pre-test and post-test is limited. Each question is only for 15 minutes.

\section{RESULTS AND DISCUSSION}

This research was conducted using 50 Diploma III of nursing students in semester 4 with Medical Surgical Nursing courses. The students were divided into two groups: the control group and the intervention group. Each group consists of 25 student groups.

Table 1. Characteristic respondent

\begin{tabular}{|c|c|c|c|c|c|c|c|c|c|}
\hline \multirow[t]{2}{*}{ No } & & \multicolumn{4}{|c|}{ Intervention Group } & \multicolumn{4}{|c|}{ Control Group } \\
\hline & & Mean & $\mathrm{SD}$ & Total & $\%$ & Mean & $\mathrm{SD}$ & Total & $\%$ \\
\hline 1 & Age & 20.4 & 0.50 & & & 20.56 & 0.82 & & \\
\hline \multirow[t]{3}{*}{2} & Sex & & & & & & & & \\
\hline & Women & & & 20 & 80 & & & 20 & 80 \\
\hline & Man & & & 5 & 20 & & & 5 & 20 \\
\hline
\end{tabular}

Based on table 1, it can be seen that the average age of respondents was 20.4 for the intervention group and the control group 20.56 while the standard deviation $(0.50)$ for the intervention group and $(0.82)$ for the control group. Before the intervention, there were still many respondents who did not understand the sequence or stages of doing diabetes foot exercises. After an intervention using a demonstration of diabetes foot gymnastics the respondent understands every movement by viewing the video (audio visual). Data about student scores before and after the intervention can be seen in Table 2 .

Table 2 Pre-test and post-test scores after the control group intervention

\begin{tabular}{|lcc|}
\hline \multicolumn{1}{|c|}{ Score } & Mean & Deviation st. \\
\hline Pre-test & 52 & 7.07 \\
Post test & 78 & 6.00 \\
\hline
\end{tabular}

Based on Table 2, it is shown that the average value in diabetes foot exercises before learning interventions using demonstrations in the control group is 52 and after the intervention is 78. Before intervention all respondents did not sequentially at each stage in doing diabetes foot exercises. After learning by using a demonstration, they can do the steps in sequence in each step. Data on student scores before and after the intervention can be seen in Table 3 . The value of diabetes foot exercises before and after the intervention of the treatment group.

Table 3 The value of diabetes foot exercises before and after the intervention of the treatment group

\begin{tabular}{|lcc|}
\hline \multicolumn{1}{|c|}{ Score } & Mean & Deviation st. \\
\hline Pre-test & 64 & 6.45 \\
Post test & 84 & 5.09 \\
\hline
\end{tabular}

Based on table 3, it is presented the average value in diabetic foot exercises before learning interventions using audio visual in the treatment group is 64 and after the intervention is 84 . Before the bivariate test is performed on the student practicum values, a normality test is conducted to determine the test to be used. Data normality test uses the Kolmogorov-Smirnov test. The results of the normality test can be seen in Table 4 . The results of the normality test data for pre and post intervention.

Table 4 The results of the normality test data for pre and post intervention

\begin{tabular}{|lcc|}
\hline \multicolumn{1}{|c}{ variable } & deviation st. & $\boldsymbol{p}$ \\
\hline Pre-test (Control) & 7.07 & 0.000 \\
Post-test (Control) & 6.00 & 0.005 \\
Pre-test (Intervention) & 6.45 & 0.000 \\
Post-test (Intervention) & 5.09 & 0.000 \\
\hline
\end{tabular}

Based on table 4, it is described that the $\mathrm{p}$ value of the control group after and before the intervention is 0.000 this $p$ value $<0.05$. These values indicate that there are differences in values before and after conventional demonstration learning interventions. In the $p$ value treatment group, the value is 0.000 this is $p$ value $<0.05$. This value indicates that there is a difference in nailing before and after learning interventions using audio visual. In this study, most nursing students in Diploma III semester 4 were female in the control group and the intervention group, amounting to 20 people (80\%). This is supported by Rusnawati [4] at Puri Husada Hospital obtained data that nurses are mostly dominated by female nurses. This is because the profession as a nurse is still identic with a work done by women, because this profession really needs a compassionate soul, requires high patience and maternal instincts. And male nursing students have higher grades in performing masculinity tests compared to men who study 
other subjects. Male nurses are physically needed for nursing tasks in certain matters.

The correspondent age in this study is the average age of 20 years while age 20 years includes adulthood. Adulthood is a productive age, a problematic period, a period of dependence and a creative period. Besides, it is regarded as well as a period of someone performing professional skills which can apply and develop science and technology and the arts so that it is accepting a more mature change in critical thinking [5]. The average age of the respondent is 20 years according to level 2 Diploma III in nursing.

The results showed that there were significant differences in the pre and post intervention values both in the control group and the intervention or treatment group. Thus, learning interventions using demonstration methods and visual radios affect respondents' understanding and skills in doing diabetic foot exercises. Demonstration learning method is a method that presents teaching by demonstrating and showing students on a certain situation or object, either actually or just an imitation. The video tutorial is given by the way the teaching assistant gives videos of diabetes foot exercises in class. Video tutorials used in learning are videos that are made by researchers themselves, according to Standard Operating Procedures (SOPs) or manuals prepared by supporting lecturers. The advantage of the demonstration method is that the attention of students can be more focused on the material learned, and the learning outcomes are more inherent in students as respondents [6]. Learning using video tutorials can show real skills and activities and uses that can be repeated at any time. It is also simple and can be used for learning outside the laboratory for example in the community by doing together. Learning media using video attracts the attention of students so that students will be more motivated in learning and understanding every move displayed by the video. Learning through video is more concrete compared to that without using video learning media so that the material is clearer and understood by every student.

The ability of diabetic foot exercises for students in performing these skills in a demonstration is seen from the frequency of the exercise itself which is more limited than the ability to do repetitive skills to have better abilities. Meanwhile, the experimental group of students who get learning with diabetic foot gymnastic video media can convey verbal and non-verbal impressions which can be used for classical or individual, used repeatedly and can present pictures and sounds [7]. In practicum that uses demonstration methods and VCD media, students can be more understanding if the lecturers' information is less clear in practicing diabetes foot exercises. Research conducted by Novelia, et al in the community explaining that the influence of health education through audio visual media on foot implementation knowledge in type $2 \mathrm{DM}$ patients is known to have a significant increase in knowledge, this happens because someone's knowledge can be influenced by several factors, namely education, mass media and age. In line with the theory of Notoatmodjo states that age affects the person's comprehension and mindset [8]

\section{CONCLUSION}

Based on the results of research and discussion, the use of instructional media with audio visual conclusions are: identified characteristics of respondents with an average age of 20 years with an average gender is female, identified average value Indicates that the $p$ value of the control group after and before the intervention is $0,000 \mathrm{p}$ value $<0.05$. These values indicate that there are differences in values before and after conventional demonstration learning interventions. In the treatment group the value of $p$ value is 0.000 this $p$ value $<0.05$. This value indicates that there is a difference in nailing before and after learning interventions using audio visual.

\section{ACKNOWLEDGMENT}

Our gratitude goes to the Research and Community Service Institute of the Universitas Muhammadiyah Magelang for the financial support and facilities provided, and to student Fitri Dewi Kinasih for her contribution in the research process.

\section{REFERENCES}

[1] D. Nugroho, "Pengembangan Media Pembelajaran Berbasis Multimedia Interaktif Pada Mata Pelajaran Teknik Elektronika Dasar Di Smk Negeri 1 Bansari Temanggung," 2016.

[2] Y. Asri, Pengaruh Penggunaan Media Pembelajaran Video Belajar Ketrampilan Memasang Infus Pada Mahasiswa S1 Keperawatan Stikes Kendedes Program Pascasarjana Mahasiswa S1 Keperawatan Stikes Kendedes. 2009.

[3] Donkor, "Assessment Of Learner Acceptance And Satisfaction With Video-Based Instructional Materials For Teaching Practical Skills At A Distance,” 2010.

[4] N. R. Rusnawati, "Relasi Gender Dalam TugasTugas Keperawatan Di Rumah Sakit Puri Husada Sleman Yogyakarta Skripsi,"עלון הנוטע, Vol. 66, Pp. 37-39, 2012.

[5] M. Hanifah Et Al., "Hubungan Usia Dan Tingkat Pendidikan Dengan Pengetahuan Wanita Usia 20-50 Tahun Tentang Periksa Payudara Sendiri ( Sadari ) ( Studi Di Rt 05 Dan Rt 06 Rw 02 Kelurahan Rempoa Pada Tahun 2010 ),” 2010.

[6] F. A. Setianingsih, "Perbedaan Metode Video Tutorial Dan Simulasi Dengan Demonstrasi Terhadap Kompetensi Mahasiswa Keperawatan Dalam 
[8] N. W. Dari, S. Nurchayati, And O. Hasanah, "Pengaruh Pendidikan Kesehatan Senam Kaki Melalui Media Audio Visual Terhadap Pengetahuan Pelaksanaan Senam Kaki Pada Pasien Dm Tipe 2," 2012.
[7] N. H. Waryanto, "Penggunaan Media Audio Visual

Dalam Menunjang Pembelajaran,” Pp. 1-8, 2007.
Melakukan Skills Tracheostomy Care Di Universitas Muhammadiyah Surakarta D,” 2017. 